\title{
Genetic differentiation in Aspidosperma polyneuron (Apocynaceae) over a short geographic distance as assessed by AFLP markers
}

J.O. Damasceno' ${ }^{1}$, E.A. Ruas ${ }^{1,2}$, L.A. Rodrigues ${ }^{2}$, C.F. Ruas ${ }^{2}$, E. Bianchini' J.A. Pimenta ${ }^{3}$ and P.M. Ruas ${ }^{1,2}$

${ }^{1}$ Departamento de Agronomia, Centro de Ciências Agrárias, Universidade Estadual de Londrina, Londrina, PR, Brasil

${ }^{2}$ Departamento de Biologia Geral, Centro de Ciências Biológicas, Universidade Estadual de Londrina, Londrina, PR, Brasil

${ }^{3}$ Departamento de Biologia Animal e Vegetal, Centro de Ciências Biológicas, Universidade Estadual de Londrina, Londrina, PR, Brasil

Corresponding author: P.M. Ruas

E-mail: ruas@sercomtel.com.br

Genet. Mol. Res. 10 (2): 1180-1187 (2011)

Received October 25, 2010

Accepted December 9, 2010

Published June 21, 2011

DOI 10.4238/vol10-2gmr1126

\begin{abstract}
Studies on intraspecific variation can contribute to the development of conservation strategies by identifying units of conservation for threatened species. Aspidosperma polyneuron is a tropical tree of seasonal semideciduous forests that is currently endangered and protected because it has been heavily logged for lumber, although it was once common in Brazil and neighboring countries. We investigated genetic structure in two samples of A. polyneuron collected from steep hillsides and from flat areas of a natural forest fragment in northern Paraná State, Brazil. Seven AFLP primer combinations yielded 200 markers, with a polymorphic rate of $88.5 \%$ for samples from the flat area and $99 \%$ for samples from the high declivity area. Total genetic diversity $\left(H_{\mathrm{T}}\right)$ was 0.387 , while the genetic diversity
\end{abstract}


within the populations $\left(H_{\mathrm{S}}\right)$ was 0.307 and 0.372 , for samples from the flat and the high declivity areas, respectively. Genetic differentiation between samples was high, with a mean $F_{\text {ST }}$ of 0.265 and a genetic distance of 0.148 , indicative of a high degree of genetic structure over a short distance. Principal coordinate analysis separated the samples into three groups of individuals; the first group included individuals from the high declivity area, the second group consisted of individuals only from the flat area, and the third group had individuals from both areas. Bayesian analysis also showed $\mathrm{K}=3$ clusters. The unexpected high level of intraspecific variation of A. polyneuron in this small forest fragment should be taken into account when evaluating the genetic impact of forest degradation on this species in other semideciduous forest fragments.

Key words: Conservation genetics; AFLPs; Genetic variability; Tropical forest fragment

\section{INTRODUCTION}

Habitat fragmentation and disturbance due to deforestation, weed invasion, fire, and the introduction of animals may directly reduce the actual size of plant populations and alter the abundance and effectiveness of pollinators and seed dispersers (Lamont et al., 1993; Aizen and Feinsinger, 1994; Kremen and Ricketts, 2000). Such factors may lead these populations to face reduction in diversity, genetic isolation and an increase in endogamy. When these processes are strengthened they may lead populations to greatly reduce their adaptability and even undergo extinction (Frankham, 1995; Newman and Pilson, 1997; Saccheri et al., 1998).

Aspidosperma polyneuron Muell. Arg (Apocynaceae) is a long-lived tropical tree species that can reach over 1200 years (Carvalho, 1994). The trees have a slow growth rate, taking 10 to 15 years to increase $5 \mathrm{~cm}$ in diameter at breast height and around 50 years to reach the reproductive stage (Torezan et al., 2005). This species grows to 20-30 m in height and its trunk can reach 60 to $90 \mathrm{~cm}$ in diameter. The species blooms from October to November with fruit maturation occurring from August to September, producing a large quantity of winged seeds with anemocoric dispersion, at intervals of 2 to 4 years. Pollen dissemination is probably carried out by moths and/or small insects (Morellato and Leitão-Filho, 1995).

With a broad range of distribution $A$. polyneuron can be found from $10^{\circ} \mathrm{N}$ (Venezuela) to $25^{\circ} 50^{\prime} \mathrm{S}$ (Brazil), at altitudes of 80 to $1000 \mathrm{~m}$ and under mean annual rainfall of 1100 to 2500 $\mathrm{mm}$ (Carvalho, 1994). In Brazil, this species can be found in deep and fertile soils on ridges and slopes of seasonal semideciduous forests, in the States of Bahia, Mato Grosso do Sul, Minas Gerais, Goiás, Mato Grosso, Rondônia, and Paraná. From an ecological standpoint, $A$. polyneuron is considered to be one of the most important species for recuperation of degraded heterogeneous forests (Carvalho, 1994; Lorenzi, 2002). Nevertheless, this tree is in danger of extinction in the State of Paraná, as a consequence of the habitat fragmentation driven by agriculture and the economic exploitation of its heavy and compact wood that has been used in construction and furniture (Hatschbach and Ziller, 1995; Ribas et al., 2005). The species has also been exploited due to its chemical compounds, which include alkaloids, saponins and es- 
sential oils (Schumutz, 1960; Marcondez-Ferreira Neto, 1988). The objective of the present study was to determine whether there are differences in the genetic structure between samples of A. polyneuron from two different microhabitats of a semideciduous forest fragment.

\section{MATERIAL AND METHODS}

\section{Characterization of the study area}

The study area covered $1.7 \mathrm{~km}^{2}$, at an altitude of $464 \mathrm{~m}$, of a seasonal semideciduous

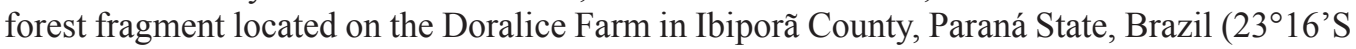
and $\left.51^{\circ} 03^{\prime} \mathrm{W}\right)$. This area is surrounded by monoculture crops, orchards and grasslands. The fragment exhibits an area of high declivity, close to the banks of the Tibagi River and, further ahead, the topography gradually softens until becoming almost flat. Whereas the flat portion of the fragment displays deep clay soil, with a high level of humidity and a lower availability of light under the canopy, the high declivity area presents soil that is weaker in nutrients, shallower with rocky outcroppings (Soares-Silva and Barroso, 1992). Plant density also varied between the two portions of the fragment, with the flat area exhibiting greater canopy cover and higher density of individuals than in the high declivity area (Costa, 2009).

Plants of A. polyneuron were sampled from the high declivity area and the flat area, at a minimal distance of about $200 \mathrm{~m}$ between areas, taking into account plants in the prereproductive phase, with a maximum stature of $2 \mathrm{~m}$. Young leaves of 30 individuals were sampled from each area at a minimum distance of $30 \mathrm{~m}$ between individual plants to minimize sampling of siblings.

\section{DNA isolation and amplified fragment length polymorphism (AFLP) reactions}

Genomic DNA was isolated from approximately $0.5 \mathrm{~g}$ fresh leaves using the CTAB method, as described by Doyle and Doyle (1987). AFLPs were carried out as described by Vos et al. (1995). Briefly, DNA samples were submitted to restriction with EcoRI/MseI endonucleases $\left(5 \mathrm{U}\right.$ each) and binding to their respective adapters. After incubation for $16 \mathrm{~h}$ at $37^{\circ} \mathrm{C}$, samples were diluted (1:10) in ultrapure water. Polymerase chain reaction (PCR) amplification was carried out using pre-selective primers complementary to the adapters with addition of one 3 ' nucleotide and diluted 1:10. For selective amplification, an initial screening was carried out with four individuals from each area using 16 primer combinations. Seven primer combinations were chosen for selective PCR: EcoRI-AGC/MseI-CAC, EcoRI-AGC/MseI-CAG, EcoRI-AGC/MseI-CAT, EcoRI-AGC/MseI-CTA, EcoRI-ACG/MseI-CAT, EcoRI-ACG/MseI$\mathrm{CAC}$, and EcoRI-AGC/MseI-CA. The products of selective amplification were separated into polyacrylamide gels 7\% (29:1) acrylamide:bis-acrylamide for $3 \mathrm{~h}$ at $200 \mathrm{~V}$ and stained with $20 \%$ silver nitrate. A 50-bp molecular ladder (Ludwig Biotecnologia, Ltda.) was used to determine the molecular weights of the fragments. Amplified fragments of between 50 to $1000 \mathrm{bp}$ were used to create a presence/absence matrix.

\section{Data analysis}

Estimation of allele frequencies and genetic diversity of populations using dominant 
markers may prove to be problematic (Zhivotovsky, 1999; Alexander et al., 2004). The possibility of statistical deviations could be eliminated through highly polymorphic data (Krauss, 2000). It is already known that, in order to obtain precise estimates of population genetic parameters, a high number of AFLP loci should be used, with a minimum of 30 individuals per population (Tero et al., 2003). Therefore, we used the dBoot v 1.1 software (Coelho, 2001) to estimate the coefficient of variation (cv) for the number of AFLP markers, generating a parameter that is capable of determining the reliability of the results of statistical analyses. The percentage of polymorphic loci $\left(P_{\mathrm{p}}\right)$, Nei's genetic diversity $\left(H_{\mathrm{S}}\right.$; Nei, 1978), Shannon index $(I)$, and genetic distance (Nei, 1972) were calculated, using POPGENE v. 1.31 (Yeh et al., 2000). Analysis of molecular variance (AMOVA) was estimated using Arlequin v. 3.11 (Excoffier et al., 2005) to evaluate the distribution of genetic variation within and among samples, as well as to estimate the $F_{\mathrm{ST}}$ index. Principal coordinate analysis (PCoA) was used to evaluate the distribution of genetic distance in clusters with the FAMD software (Schlüter and Harris, 2006). The reliability of these clusters was tested with a Bayesian clustering analysis using the STRUCTURE software (Pritchard et al., 2000).

\section{RESULTS AND DISCUSSION}

\section{Genetic variability of samples}

Seven selective primer combinations, applied to 60 individual A. polyneuron plants, yielded 200 reproducible AFLP markers with an average number of 28.57 markers per primer combination. The $\mathrm{cv}$ for the total number of markers was below $1 \%$, showing the high consistency of the AFLP data. The percentage of polymorphic loci was $88.5 \%$ for samples from the flat area and $99 \%$ for samples from the high declivity area. The values of $H_{\mathrm{S}}(\mathrm{Nei}, 1978)$ were 0.307 and 0.372 for samples from the flat and the high declivity areas, respectively. Total genetic diversity $\left(H_{\mathrm{T}}\right)$ was 0.387 and $I$ were 0.460 and 0.549 , for samples from the flat and the high declivity regions, respectively (Table 1). Torezan et al. (2005) used random amplified polymorphic DNA (RAPD) markers to assess genetic variation in samples A. polyneuron from six forest fragments, including five fragments that had been severely impacted by anthropic exploitation and one fragment within a conservation unit that is free of anthropogenic factors. The authors found fairly low values of $H_{\mathrm{T}}=0.278$, even when only the conservation unit was considered $\left(H_{\mathrm{S}}=0.285\right.$ and $I=0.387$ ), compared to those in this study (Table 1). The genetic diversity in the flat area of the Doralice farm forest fragment had recently suffered the anthropogenic effects of selective logging of adult trees. However, no dramatic effects on genetic variability are visible in the remaining plant population of the next generation, as demonstrated by the estimated genetic parameters.

Table 1. Genetic parameters estimated on the basis of 200 AFLP markers for two samples of Aspidosperma polyneuron from a forest fragment on the Doralice Farm, in Ibiporã County, Paraná State, Brazil.

\begin{tabular}{lccc}
\hline Population & $P_{\mathrm{P}}$ & $H_{\mathrm{S}}$ & $I$ \\
\hline Declivity & 99.0 & 0.372 & 0.549 \\
Flat & 88.5 & 0.307 & 0.460 \\
$H_{\mathrm{T}}$ & 0.387 & & \\
Genetic distance & 0.148 & & \\
\hline
\end{tabular}

Percentage of polymorphic loci $\left(P_{\mathrm{p}}\right)$, genetic diversity within areas $\left(H_{\mathrm{S}}\right)$, Shannon index $(I)$, total genetic diversity $\left(H_{\mathrm{T}}\right)$, and genetic distance (Nei, 1972). 
Several studies regarding genetic variability in tropical trees have shown similar results to the ones presented here. De Carvalho et al. (2008) using RAPD markers reported high genetic variability in a population of Luehea divaricata Mart. found in a declivity area, while Pither et al. (2003) found $I$ values varying from 0.320 to 0.380 for Terminalia amazônia (J. Gmell) Exell. In Swietenia macrophylla King, Gillies et al. (1999) found an I of 0.350, and Aide and Rivera (1998) found a value of 0.590 for Poulsenia armata (Miq.) Standl. Comparatively, it can be demonstrated that A. polyneuron of the fragment on the Doralice Farm maintains a good level of genetic variability.

\section{Genetic structure}

AMOVA showed that $73.52 \%$ of the genetic variability was distributed within the sampled areas and $26.48 \%$ between areas (Table 2). Aspidosperma polyneuron is an allogamous species, probably fertilized by moths and/or small insects (Morellato and Leitão-Filho, 1995), and with wind dispersed seeds (Carvalho, 1994). As stated by Maguire et al. (2002), it is common for cross-fertilization species to present a higher percentage of variability within groups than among groups. Considering the plants studied, which were sampled from two areas located within a short (about $200 \mathrm{~m}$ ) distance of each other, it is important to highlight the incidence of individuals of this species between areas, evidencing the occurrence of gene flow between the sampled areas.

Table 2. Analysis of molecular variance (AMOVA) applied to AFLP markers, for two samples of Aspidosperma polyneuron from one forest fragment of the Doralice Farm, in Ibiporã County, Paraná State, Brazil.

\begin{tabular}{lcccc}
\hline Source of variation & d.f. & Sum of squares & Variance components & \% of variance \\
\hline Between populations & 1 & 362.501 & 9.00197 & $26.48^{* *}$ \\
Within population & 73 & 1824.085 & 24.98747 & 73.52 \\
Total & 74 & 2186.587 & 33.98944 & \\
Fixation index & $F_{\mathrm{ST}}$ & 0.26485 & & \\
\hline d.f. $=$ degrees of freedom. $* * \mathrm{P}<0.01$ (significance test from 1023 permutations).
\end{tabular}

Low levels of genetic differentiation have been observed between populations of tropical tree species within a short distance of each other (Hamrick and Loveless, 1989; Merzeau et al., 1994; Leonardi and Menozzi, 1996; Takahaski et al., 2000; Mariette et al., 2002). Nonetheless, in A. polyneuron, the genetic variability (Table 1) and genetic differentiation between areas were high $\left(F_{\mathrm{ST}}=0.265\right.$; Table 2$)$ for samples within a short distance of each other.

The use of neutral molecular markers to make inferences regarding adaptive processes is risky, unless natural selection is still in place or there is a strong connection between the selected loci and the neutral markers (Merzeau et al., 1994; Leonardi and Menozzi, 1996; Takahashi et al., 2000; Mariette et al., 2002). The AFLPs revealed a genetic distance (Nei, 1978 ) of 0.148 between samples of the two areas (Table 1). Therefore, it could be argued that the genetic differentiation observed between samples of $A$. polyneuron is related to differences in adaptation of the plants to ecological conditions in the two areas. For instance, the pattern of the flat area is represented by deeper soil with more humidity and higher $\mathrm{pH}$, higher density of individuals, greater canopy cover, and less under canopy light availability, compared to the 
high declivity area that is characterized by rocky, shallow and poor soil with lower population density. Analysis carried out on the population structure of A. polyneuron, in the same fragment studied here, showed that the distribution of plants was associated with the topographic gradient (Bianchini E, personal communication). Correlation between molecular differentiation and adaptive characteristics was observed in populations of Cedrela odorata L. (Gillies et al., 1997).

The correlation between distribution of tree species and soil and topographic variables has been presented in a variety of studies of tropical forests. Rodrigues et al. (2007) demonstrated in a community study of a seasonal semideciduous forest that the majority of species present correlation with soil fertility and texture over one topographic gradient. A similar report was presented by Carvalho et al. (2005), where they observed a reduction in the size of the forest as it grew away from the river, possibly caused by the reduction in water availability. In a study carried out in a seasonal semi-deciduous forest of the riparian vegetation of a lake, Campos and Landgraf (2001) revealed a higher diversity and abundance of plant species in areas closer to the lake.

The PCoA separated the samples into three groups of individuals (Figure 1). The first group includes individuals from the flat area; the second encompasses individuals from the high declivity area, and the last group is represented by individuals from both areas. This might be related to two random processes: first is that the seeds of the investigated species are wind dispersed; second, the pollinating agents, probably moths and/or small insects, are presumably able to fly distances greater than $200 \mathrm{~m}$. The group formed by individuals from flat and high declivity areas is possibly a result of hybridization of individuals from both areas. The Bayesian analysis for the $\mathrm{K}$ number of clusters $(\mathrm{K}=3)$ further supports the distribution of the genetic variation observed in the PCoA.

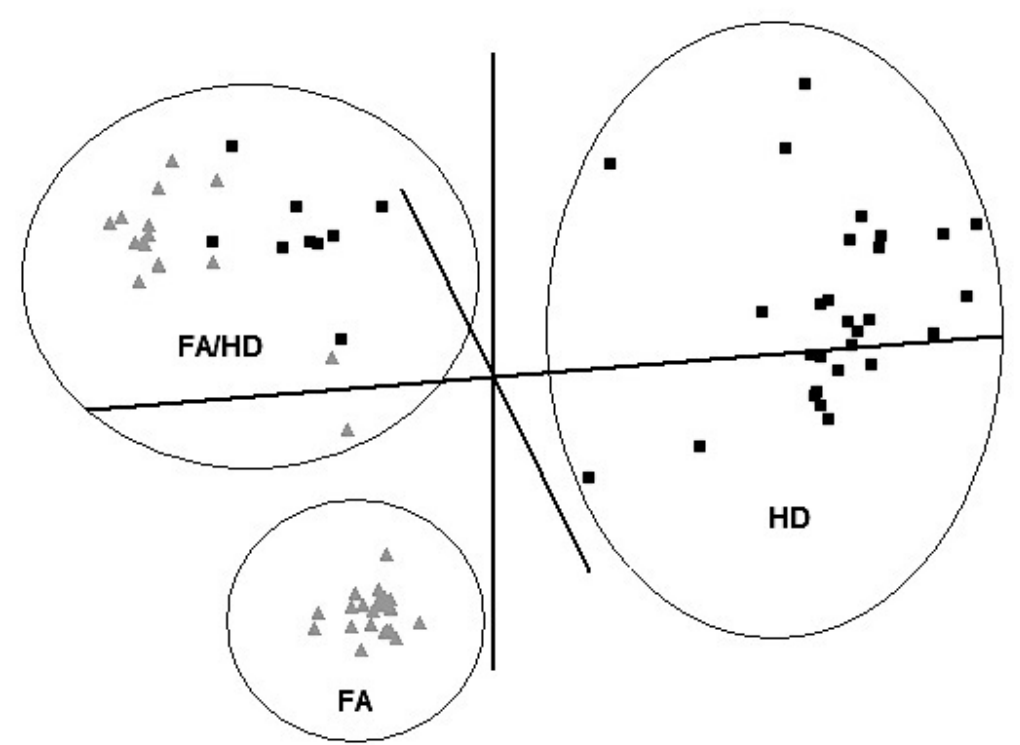

Figure 1. Principal coordinate analysis of two samples $(\mathrm{FA}=$ flat area $\mathrm{HD}=$ high declivity area $)$ of Aspidosperma polyneuron Muell. Arg. from Doralice Farm, Ibiporã County, Paraná State, Brazil. The first, second and third principal coordinates explain $30.2,11.63$, and $6.7 \%$ of the total variation, respectively. 
It is interesting to note that the genetic diversity was higher $\left(H_{\mathrm{S}}=0.372\right)$ for samples from the high declivity area than for samples from the flat area $\left(H_{\mathrm{S}}=0.307\right)$, suggesting that the occurrence of gene flow is higher in one direction, i.e., from the flat area to the declivity area. Since samples from the flat area are located at higher altitude in relation to samples from the high declivity, the wind takes more seeds towards the declivity area than towards the flat area.

Our results showed that the forest fragment on the Doralice Farm can be considered a natural reservoir of genetic diversity for A. polyneuron. This knowledge is important not only in studies of genetic structure, but also for future comparative population studies of this species to evaluate the level of genetic erosion in disturbed areas. Finally, the genetic variability found within this region can be used as source of genetic diversity for future projects regarding the recovery of degraded areas.

\section{ACKNOWLEDGMENTS}

We thank the Coordenação de Aperfeiçoamento de Pessoal de Nível Superior (CAPES), for the scholarship granted to J.O. Damasceno, and the Conselho Nacional de Desenvolvimento Científico (Process \#478179/06-5) and Fundação Araucária for financial support.

\section{REFERENCES}

Aide TM and Rivera E (1998). Geographic patterns of genetic diversity in Poulsenia armata (Moraceae): implications for the theory of Pleistocene refugia and the importance of riparian forest. J. Biogeogr. 25: 695-705.

Aizen MA and Feinsinger P (1994). Forest fragmentation, pollination, and plant reproduction in a chaco dry forest, Argentina. Ecology 75: 330-351.

Alexander JA, Liston A and Popovich SJ (2004). Genetic diversity of the narrow endemic Astragalus oniciformis (Fabaceae). Am. J. Bot. 91: 2004-2012.

Campos JC and Landgraf PRC (2001). Análise da regeneração natural de espécies florestais em matas ciliares de acordo com a distância da margem do lago. Ciênc. Flor. 11: 143-151.

Carvalho DA, Oliveira-Filho AT, Van der Berg E, Fontes MAL, et al. (2005). Structural and floristic variations of the arboreal component of a tropical upper montane rainforest on the margin of the Rio Grande, Bocaina de Minas, Brazil. Acta Bot. Bras. 19: 91-109.

Carvalho PER (1994). Espécies Florestais Brasileiras: Recomendações Silviculturais, Potencialidades e Uso da Madeira. Empresa Brasileira de Pesquisa Agropecuária. EMBRAPA-CNPF/SPI, Paraná, 533-608.

Coelho ASG (2001). Software: dBOOD - Avaliação de Dendrogramas Baseados em Estimativas de Distâncias/ Similaridades Genéticas Através do Procedimento de Bootstrap, V. 3.0. Departamento de Biologia Geral, Instituto de Ciências Biológicas, Universidade Federal de Goiás, Goiânia.

Costa JA (2009). Estudo Populacional de Aspidosperma polyneuron Mull. Arg. (Pocynaceae) em Fragmento de Floresta Estacional Semidecidual no Sul do Brasil. Master Science Dissertation, Universidade Estadual de Londrina, Londrina.

De Carvalho MCCG, Da Silva DCG, Ruas PM, Medri ME, et al. (2008). Flooding tolerance and genetic diversity in populations of Luehea divaricata. Biol. Plant. 52: 771-774.

Doyle JJ and Doyle JL (1987). A rapid DNA isolation for small quantities of leaf tissue. Phytochem. Bull. 19: 11-15.

Excoffier L, Laval G and Schneider S (2005). Arlequin (version 3.0): an integrated software package for population genetics data analysis. Evol. Bioinform. Online 1: 47-50.

Frankham R (1995). Effective population size/adult population size ratios in wildlife: a review. Genet. Res. 66: 95-107.

Gillies ACM, Cornelius JP, Newton AC, Navarro C, et al. (1997). Genetic variation in Costa Rica populations of the tropical timer species Cedrela odorata L., assessed using RAPDs. Mol. Ecol. 6: 1133-1145.

Gillies ACM, Navarro C, Lowe AJ, Newton AC, et al. (1999). Genetic diversity in mesoamerican populations of mahogany (Swietenia macrophylla), assessed using RAPDs. Heredity 83: 722-732.

Hamrick JL and Loveless MD (1989). The Genetic Structure of Tropical Tree Populations: Associations With Reproductive Biology. In: Evolutionary Ecology of Plants (Bock JK and Linhart YB, eds.). Westview Press, Boulder, 129-146.

Hatschbach GG and Ziller SR (1995). Lista Vermelha de Plantas Ameaçadas de Extinção no Estado de Paraná. Empresa 
Brasileira de Pesquisa Agropecuária. SEMA/GTZ, Curitiba, 139.

Krauss SL (2000). Accurate gene diversity estimates from amplified fragment length polymorphism (AFLP) markers. Mol. Ecol. 9: 1241-1245.

Kremen C and Ricketts T (2000). Global perspectives on pollination disruptions. Conservat. Biol. 14: 1226-1228.

Lamont WJ, Hensley DL, Wiest S and Gaussoin RE (1993). Relay-intercropping muskmelons with scotch pine christmas trees using plastic mulch and drip irrigation. HortScience 28: 177-178.

Leonardi S and Menozzi P (1996). Spatial structure of genetic variability in natural stands of Fagus sylvatica L. (beech) in Italy. Heredity 77: 359-368.

Lorenzi H (2002). Árvores Brasileiras: Manual de Identificação e Cultivo de Plantas Arbóreas Nativas do Brasil. Editora Plantarum, Nova Odessa, 384.

Maguire TL, Peakall R and Saenger P (2002). Comparative analysis of genetic diversity in the mangrove species Avicennia marina (Forsk.) Vierh. (Avicenniaceae) detected by AFLPs and SSRs. Theor. Appl. Genet. 104: 388-398.

Marcondes-Ferreira Neto W (1988). Aspidosperma Mart., nom. cons. (Apocynaceae): Estudos Taxonômicos. PhD Thesis, Universidade Estadual de Campinas, Campinas, 98.

Mariette S, Le Corre V, Austerlitz F and Kremer A (2002). Sampling within the genome for measuring within-population diversity: trade-offs between markers. Mol. Ecol. 11: 1145-1156.

Merzeau D, Comps B, ThieBaut B, Cuguen J, et al. (1994). Genetic structure of natural stands of Fagus sylvatica L. (Beech). Heredity 72: 269-277.

Morelatto PC and Leitão-Filho HF (1995). Ecologia e Preservação de uma Floresta Tropical Urbana: Reserva de Santa Genebra. UNICAMP/FAPESP, Campinas.

Nei M (1972). Genetic distance between populations. Am. Nat. 106: 283-292.

Nei M (1978). Estimation of average heterozygosity and genetic distance from a small number of individuals. Genetics 89: 583-590.

Newman D and Pilson D (1997). Increased probability of extinction due to decreased genetic effective population size: experimental populations of Clarkia pulchella. Evolution 51: 354-362.

Pither R, Shore JS and Kellman M (2003). Genetic diversity of the tropical tree Terminalia amazonia (Combretaceae) in naturally fragmented populations. Heredity 91: 307-313.

Pritchard JK, Stephans M and Donnelly P (2000). Inference of population structure using multilocus genotype data. Genetics 155: 945-959.

Ribas LLF, Zanette F, Kulchetscki L and Guerra MP (2005). Micropropagação de Aspidosperma polyneuron (perobarosa) a partir de segmentos nodais de mudas juvenis. Árvore 29: 517-524.

Rodrigues LA, Carvalho DA, Oliveira-Filho AT and Curi N (2007). Effects of soils and topography on the distribution of tree species in a fragment of tropical seasonal forest in Luminarias, SE, Brazil. Árvore 31: 25-35.

Saccheri I, Kuussaari M, Kankare M, Vikman P, et al. (1998). Inbreeding and extinction in a butterfly metapopulation. Nature 392: 491-494.

Schlüter PM and Harris SA (2006). Analysis of multilocus fingerprinting data sets containing missing data. Mol. Ecol. Notes 6: 569-572.

Schumutz J (1960). Phytochemische betrachtungen zum genus Apidosperma. Pharm. Acta Helv. 36: 103-118.

Soares-Silva LH and Barroso GM (1992). Fitossociologia do Estrato Arbóreo da Floresta na Porção Norte do "Parque Estadual Mata dos Godoy”. Congresso da Sociedade Botânica de São Paulo, Londrina, 101-112.

Takahashi M, Mukouda M and Koono K (2000). Differences in genetic structure between two Japanese beech (Fagus crenata Blume) stands. Heredity 84: 103-115.

Tero N, Aspi J, Siikamaki P, Jakalaniemi A, et al. (2003). Genetic structure and gene flow in a metapopulation of an endangered plant species, Silene tatarica. Mol. Ecol. 12: 2073-2085.

Torezan JMD, Souza RF, Ruas PM, Ruas CF, et al. (2005). Genetics variability of pre and post-fragmentation cohorts of Aspidosperma polineuron Muell. Arg. (Apocynaceae). Braz. Arch. Biol. Tech. 48: 171-180.

Vos P, Hogers R, Bleeker M, Reijans M, et al. (1995). AFLP: a new technique for DNA fingerprinting. Nucleic Acids Res. 23: 4407-4414.

Yeh FC, Yang R, Boyle TJ and Xiyan JM (2000). Pop Gene 32. Microsof Window-Based Freeware for Population Genetic Analysis. Molecular Biology and Biotechnology Center, University of Alberta, Edmonton, 32.

Zhivotovsky LA (1999). Estimating population structure in diploids with multilocus dominant DNA markers. Mol. Ecol. 8: 907-913. 